Article

\title{
Increasing the Performance of Vacuum Membrane Distillation Using Micro-Structured Hydrophobic Aluminum Hollow Fiber Membranes
}

\author{
Chia-Chieh Ko ${ }^{1}$, Chien-Hua Chen ${ }^{1}$, Yi-Rui Chen ${ }^{1}$, Yu-Hsun Wu ${ }^{1}$, Soon-Chien Lu ${ }^{1}$, \\ $\mathrm{Fa}-\mathrm{Chun} \mathrm{Hu}^{2}$, Chia-Ling $\mathrm{Li}^{2}$ and Kuo-Lun Tung ${ }^{1, *}$ \\ 1 Department of Chemical Engineering, National Taiwan University, Taipei 106, Taiwan; \\ jackko0213@gmail.com (C.-C.K.); jefferychen1986@gmail.com (C.-H.C.); \\ yi.rui.chen.rex@gmail.com (Y.-R.C.): b00504074@ntu.edu.tw (Y.-H.W.); durvlee2001@hotmail.com (S.-C.L.) \\ 2 Material and Chemical Research Laboratories, Industrial Technology Research Institute, \\ Hsinchu 310, Taiwan; frankiehu@itri.org.tw (F.-C.H.); clli@itri.org.tw (C.-L.L.) \\ * Correspondence: kuolun@ntu.edu.tw; Tel.: +886-2-3366-3027; Fax: +886-2-2362-3040
}

Academic Editor: Enrico Drioli

Received: 29 January 2017; Accepted: 1 April 2017; Published: 4 April 2017

\begin{abstract}
This study develops a micro-structured hydrophobic alumina hollow fiber with a high permeate flux of $60 \mathrm{Lm}^{-2} \mathrm{~h}^{-1}$ and salt rejection over $99.9 \%$ in a vacuum membrane distillation process. The fiber is fabricated by phase inversion and sintering, and then modified with fluoroalkylsilanes to render it hydrophobic. The influence of the sintering temperature and feeding temperature in membrane distillation (MD) on the characteristics of the fiber and MD performance are investigated. The vacuum membrane distillation uses $3.5 \mathrm{wt} \% \mathrm{NaCl}$ aqueous solution at $70{ }^{\circ} \mathrm{C}$ at $0.03 \mathrm{bar}$. The permeate flux of $60 \mathrm{Lm}^{-2} \mathrm{~h}^{-1}$ is the highest, compared with reported data and is higher than that for polymeric hollow fiber membranes.
\end{abstract}

Keywords: membrane distillation; vacuum membrane distillation; ceramic hollow fiber membrane; hydrophobicity; water desalination

\section{Introduction}

The availability of fresh water is limited. Even though almost $70 \%$ of the earth's surface is covered by water, more than $97 \%$ of water is in the oceans, leaving only $3 \%$ for consumption by human and animal life [1,2]. The rapid development of technology has shown that a supply of fresh water is critical. However, large amounts of energy are required to obtain fresh water using conventional equipment [3].

Membrane separation processes are an emerging technology that feature low energy consumption, especially membrane contactors with porous membranes $[4,5]$. Therefore, there have been many studies of membrane distillation (MD) processes in the last two decades [6-8]. MD is frequently used for seawater desalination due to the easy driving force of slight temperature differences [6,9-11]. Membrane contactors could resolve the fresh water problem. However, compared to conventional separation processes, there is extra resistance owing to the membrane in membrane contactors. In other words, the features of the membrane seriously affect the overall performance of membrane contactors.

At present, membranes used extensively in membrane contactors are organic polymer membranes, due to their higher porosity and thinness [12-14]. However, the poor chemical resistance and the ease with which organic polymer membranes swell make them unsuitable for chronic continuous operation. Few studies use inorganic ceramic membranes for membrane contactors because of lower porosity, which results from the sintering process that is used for ceramic membrane production. The hydrophilic 
nature of inorganic ceramic membranes also renders them inapplicable to membrane contactors. Inorganic ceramic membranes have potential in this area because of their outstanding thermal and chemical resistance and high mechanical strength [15-19]. The production of a hydrophobic, porous ceramic membrane is key to its success.

For membranes with various geometries, hollow fiber membranes have been widely studied because of their potential for low mass transfer resistance and high packing density $[4,5,20]$. Whether organic polymer or inorganic, ceramic hollow fiber membranes are generally fabricated using phase inversion, which is also a common way to produce the membrane for MD [3]. Phase inversion produces a hollow fiber with a symmetric or asymmetric structure that can be tuned by varying the operational parameters and the composition of the suspension, the bore fluid and coagulation [20-22]. This study fabricates hydrophobic ceramic fiber membranes for vacuum membrane distillation (VMD) using a high performance via phase-inversion/sintering method.

\section{Experimental}

\subsection{Fabrication of Alumina Hollow Fiber Membranes}

A combined phase-inversion and sintering method was used to fabricate the alumina hollow fiber membranes. The dispersant poly-ethyleneglycol 30-dipolyhydroxystearate (ARLACEL-P135, Croda Taiwan, Taoyuan, Taiwan, molecular weight: $5000 \mathrm{~g} / \mathrm{mol}$ ) was firstly dissolved in $N$-methyl2-pyrrolidone (NMP) (TEDIA, Echo Chemical, Taipei, Taiwan, purity $>99 \%$ ) and stirred to form a homogeneous solution. Aluminum oxide powder (Alfa Aesar, Uni-onward, New Taipei, Taiwan, $\alpha$-phase $>99.9 \%$, average particle size: $1.0 \mu \mathrm{m}$ ) and polyethersulfone (PESf) (Veradel A-301, SOLVAY, Trump Chemical, Taipei, Taiwan, amber color) were then added into the solution gradually and stirred for $48 \mathrm{~h}$ to form a continuous suspension. The weight percentages of aluminum oxide powder, polymer $\mathrm{PES}_{\mathrm{f}}$, solvent NMP and dispersant ARLACEL-P135 in the suspension were $49.5 \mathrm{wt} \%, 9.9 \mathrm{wt} \%$, $39.6 \mathrm{wt} \%$, and $0.99 \mathrm{wt} \%$, respectively. The as-prepared suspension was transferred to a plastic injector and then extruded through a spinneret (outer diameter $2.0 \mathrm{~mm}$, inner diameter $1.0 \mathrm{~mm}$ ) from the injector, using a syringe pump. Deionized water was used as a bore fluid and pumped to the spinneret. After passing an air gap, the extruded suspension entered into a coagulation bath of deionized water that was used as a non-solvent for further solvent exchange, to obtain green fiber. This deionized water was renewed every $12 \mathrm{~h}$ to ensure a fresh non-solvent supply over a period of 2 days. The details of the spinning parameters are shown in Table 1.

After drying at room temperature, the as-prepared green hollow fiber was heated in a furnace at a rate of $1.6^{\circ} \mathrm{C} / \mathrm{min}$ to $480^{\circ} \mathrm{C}$ and held at $480^{\circ} \mathrm{C}$ for $12 \mathrm{~h}$, followed by heating to specific temperature $\left(1400\right.$ or $\left.1500{ }^{\circ} \mathrm{C}\right)$ at a rate of $2{ }^{\circ} \mathrm{C} / \mathrm{min}$. It was then maintained for $2 \mathrm{~h}$. The entire sintering process was performed in an air environment.

Table 1. The spinning parameters used in this study.

\begin{tabular}{cc}
\hline Parameters & Value \\
\hline Suspension flow rate $(\mathrm{mL} / \mathrm{min})$ & 15 \\
Bore fluid flow rate $(\mathrm{mL} / \mathrm{min})$ & 10 \\
Air gap $(\mathrm{cm})$ & 20 \\
\hline
\end{tabular}

\subsection{Fiber Hydrophobization}

Fluoroalkylsilanes (FAS) $(1 \mathrm{H}, 1 \mathrm{H}, 2 \mathrm{H}, 2 \mathrm{H}$-perfluorooctyltriethoxysilane) (Echo Chemical, Taipei, Taiwan, purity $>95 \%$, molecular weight: $510.36 \mathrm{~g} / \mathrm{mol}$ ) as a hydrophobilizing agent were used to attach with the hydroxyl group on the as-sintered hollow fiber using an immersion method. The as-sintered hollow fiber was immersed into a $0.02 \mathrm{M}$ FAS solution of n-hexane, which was the same concentration used in previous work, at $40^{\circ} \mathrm{C}$ for $48 \mathrm{~h}$ and the FAS solution was refreshed every $24 \mathrm{~h}$. This was 
followed by drying at room temperature, to produce a hydrophobic fiber. Finally, the hydrophobic fibers were stored in an ambient atmosphere followed by module procedure and MD.

\subsection{Characterization}

The membrane's hydrophobicity was quantified by measuring the apparent contact angle (CA) value before and after hollow fiber hydrophobization, to determine the hydrophobicity of the fiber surface.

A Scanning Electron Microscope (SEM) was utilized to observe the morphology and microstructure of the hollow fiber.

Hollow fibers were characterized by an extrusion method, using a mercury porosimeter to determine the porosity, the average pore size and the distribution of the pore size.

Pure water permeation was carried out using a home-made device before and after hollow fiber hydrophobization. One end of the hollow fiber was sealed with epoxy resin and then fixed at the outlet of a stainless pipe and covered. Deionized water was fed into the stainless pipe and pressurized by nitrogen at various pressures. The weight of the liquid deionized water penetrating from outside to inside through the hollow fiber was recorded using an electronic balance.

Liquid entry pressure of water $\left(\mathrm{LEP}_{\mathrm{w}}\right)$, defined as the pressure at which water penetrates through the hydrophobic hollow fiber, used the same device as that used for pure water permeation. The $\mathrm{LEP}_{\mathrm{w}}$ value is a critical parameter for the hydrophobicity level of the hollow fiber and determines whether it is applicable for the MD process.

\subsection{Fiber Module}

The module procedure of hydrophobic fiber was required before membrane distillation. The fiber module contained a hydrophobic hollow fiber and glass shell. The hollow fiber with a length of $9 \mathrm{~cm}$ was incorporated into the glass shell with a $1.8 \mathrm{~cm}$ inner diameter and a length of $10.4 \mathrm{~cm}$ using epoxy resin. There was one inlet and one outlet for the shell side and only one outlet for the permeate side, whereas the other side of fiber was sealed, as shown in Figure 1.

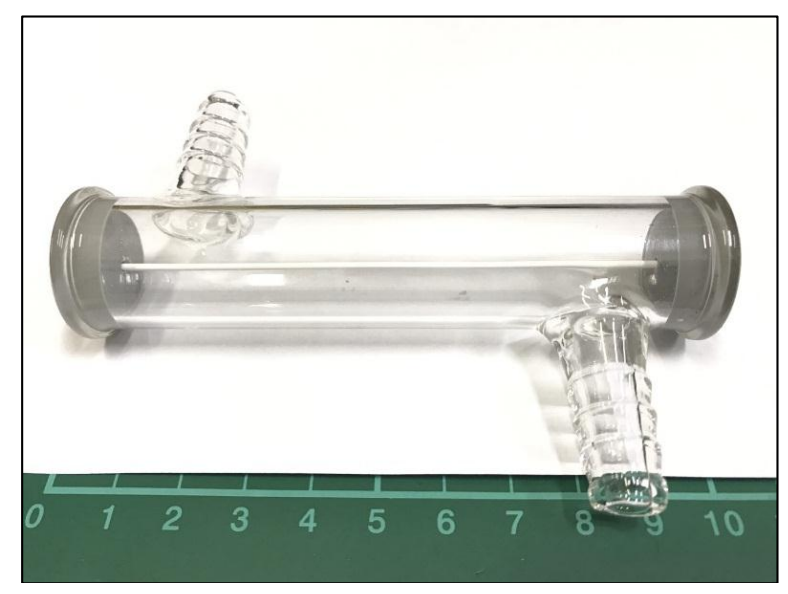

Figure 1. Hydrophobic aluminum hollow fiber module.

\subsection{Membrane Distillation}

Membrane performance was assessed using a home-made VMD configuration with a hollow fiber module. $\mathrm{NaCl}$ aqueous solution at a concentration of $3.5 \mathrm{wt} \%$ was heated to $70{ }^{\circ} \mathrm{C}$ and circulated at a flow rate of $1 \mathrm{~L} / \mathrm{min}$ into the shell side, as the feed side of the module. The pressure of the lumen side, which is generally called the permeate side, was maintained at 0.03 bar using the vacuum pump. The water vapor that was transported from the shell side to the lumen side of the module was condensed and collected in a trap bottle using liquid nitrogen. The permeate flux and the rejection of 
the VMD process were determined by measuring the weight as a function of time and the conductivity of the condensing water, respectively.

\section{Results and Discussion}

The general temperature used in the sintering process to fabricate the ceramic hollow fiber membrane is about 1300 to $1500{ }^{\circ} \mathrm{C}$, therefore the sintering temperatures of 1400 and $1500{ }^{\circ} \mathrm{C}$ are investigated in this study. SEM analysis confirmed the morphologies of the as-sintered alumina hollow fiber membrane sintered at 1400 and $1500{ }^{\circ} \mathrm{C}$. As shown in Figure 2a,b, the alumina grain size of the outer surface sintered at $1400{ }^{\circ} \mathrm{C}$ is slightly smaller than that at $1500{ }^{\circ} \mathrm{C}$, and for both the outer surface consists of visible alumina grains and a preliminary result for the pore size of several hundred micrometer are evident. From the cross-sectional SEM images (Figure 2c,d) of the as-sintered alumina hollow fiber membrane, it is seen that a symmetrical fiber with an inner and outer diameter of 0.8 and $1.2 \mathrm{~mm}$ for $1400{ }^{\circ} \mathrm{C}$ sintering and that of 0.8 and $1.3 \mathrm{~mm}$ for $1500{ }^{\circ} \mathrm{C}$ sintering are produced. Figure 2e,f both show the typical microstructure that results from the phase-inversion method. For both fabrications sintered at 1400 and $1500{ }^{\circ} \mathrm{C}$, a finger-like structure extends from two surfaces and a sponge like structure fills the middle part, which shows that the spinning procedure is successful. The finger-like structure, which occupies at least $70 \%$ of the entire structure, observed in Figure 2e, is slightly more than that observed in Figure 2f, and the more finger-like structure may result in a better permeating characteristic.

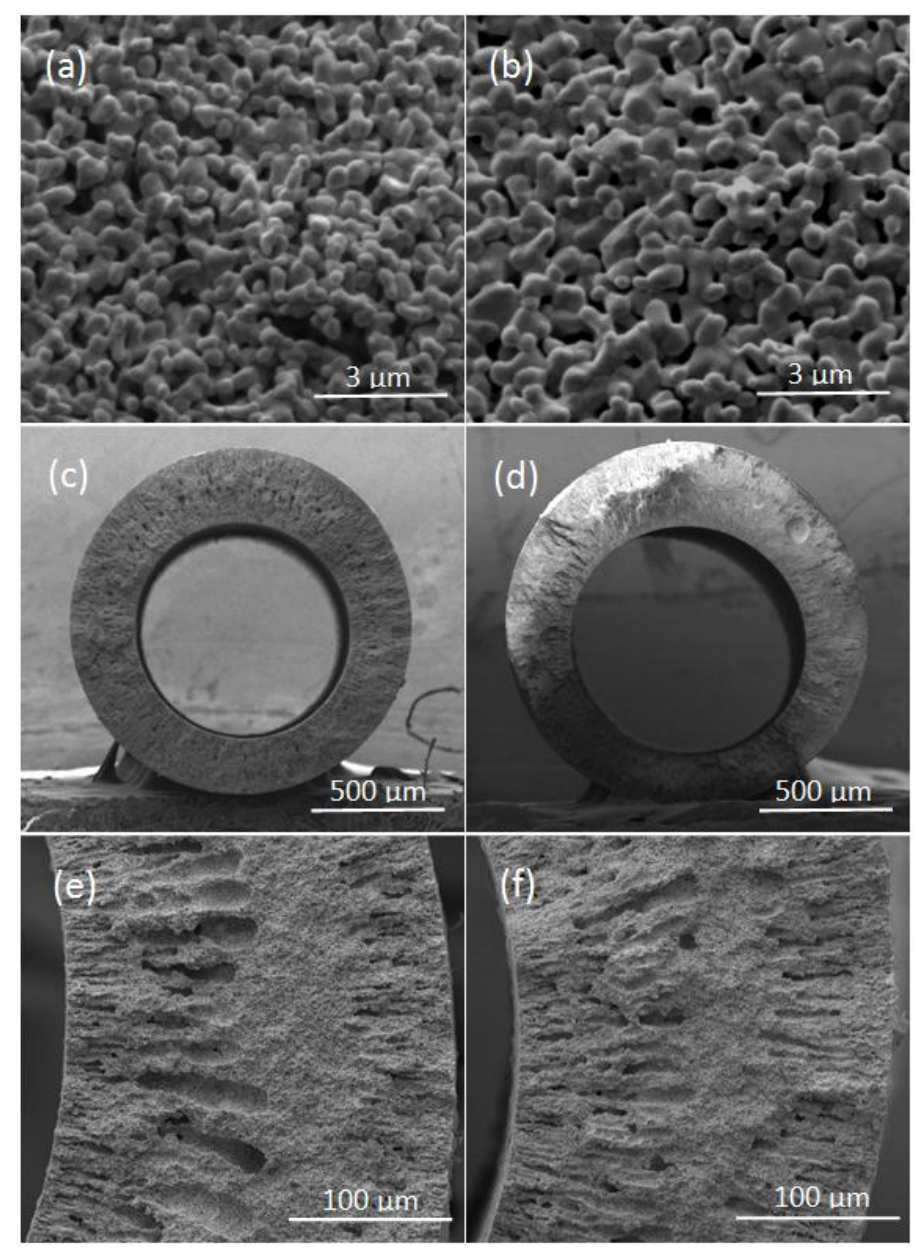

Figure 2. The morphologies of the as-sintered alumina hollow membrane sintered at different temperatures: outer surface sintered at (a) $1400^{\circ} \mathrm{C}$ and (b) $1500{ }^{\circ} \mathrm{C}$; cross-sectional sintered at (c) $1400^{\circ} \mathrm{C}$ and (d) $1500{ }^{\circ} \mathrm{C}$; partial cross-sectional sintered at (e) $1400^{\circ} \mathrm{C}$ and (f) $1500{ }^{\circ} \mathrm{C}$. 
The mercury porosimeter results for the as-prepared fiber are shown in Figure 3. It is seen that both of the pore size measurements are in the range of 100 to $400 \mathrm{~nm}$, that give average pore size of about 220 and $165 \mathrm{~nm}$ for 1400 and $1500{ }^{\circ} \mathrm{C}$ sintering, respectively. They both are consistent with the appropriate pore size of 0.1 to $1 \mu \mathrm{m}$ that has been reported for MD. In addition, the porosities of $55 \%$ and $33 \%$ were measured for the materials sintered at 1400 and $1500{ }^{\circ} \mathrm{C}$, respectively.

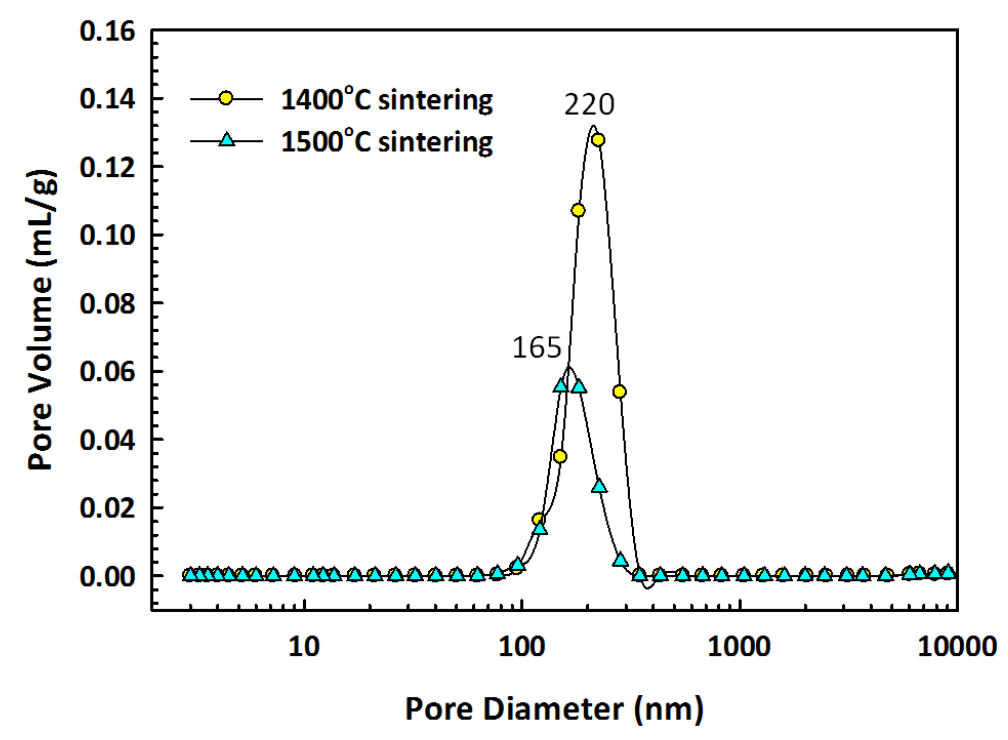

Figure 3. Pore size distribution, as measured by a mercury porosimeter.

The as-sintered hollow fiber is intrinsically hydrophilic because of the presence of hydroxyl groups on the fiber. In order to use the fiber for MD, FAS, which is a general agent for hydrophobization, was used to hydrophobilize the fiber by the method mentioned previously. A pure water permeation test was carried out before and after hydrophobization, to determine the permeability and the $\mathrm{LEP}_{\mathrm{w}}$ value which determines the applicability for MD.

The results of the pure water permeation as a function of the pressure difference between the feed and permeate sides are shown in Figure 4. The pure water fluxes of the fiber sintered at 1400 and $1500{ }^{\circ} \mathrm{C}$ both increase almost linearly with pressure difference before hydrophobization, and pure water fluxes of about 3000 and $2600 \mathrm{Lm}^{-2} \mathrm{~h}^{-1} \mathrm{bar}^{-1}$ are recorded. The higher pure water flux of $3000 \mathrm{Lm}^{-2} \mathrm{~h}^{-1} \mathrm{bar}^{-1}$ is attributed to the larger average pore size $(220 \mathrm{~nm})$ and the higher porosity $(55 \%)$ mentioned above. However, the water flux could not be detected after hydrophobization until a specific pressure difference, which means the $L_{E P}$ value. The $L E P_{w}$ value of 2.5 bar for $1400{ }^{\circ} \mathrm{C}$ sintering (Figure 4c) is lower than that of 4.5 bar for $1500{ }^{\circ} \mathrm{C}$ sintering (Figure 4d), and this result is in accordance with the larger average pore size of $220 \mathrm{~nm}$. Both $\mathrm{LEP}_{\mathrm{w}}$ values are higher than the pressure difference of about 1.0 bar used in VMD, which also demonstrates the applicability. Figure $4 \mathrm{e}, \mathrm{f}$ also shows the hydrophobicity with contact angles both at about $137^{\circ}$. Furthermore, it has been reported that the FAS modification only reduces the pore size of the fiber slightly for several nanometers.

After characterization, the as-prepared hydrophobic fiber modules were used for MD. VMD was used because of its high permeate flux. The $3.5 \mathrm{wt} \% \mathrm{NaCl}$ aqueous solution was circulated at the shell side and the permeate water was collected at the tube side at 0.03 bar every $30 \mathrm{~min}$. As shown in Figure 5, the permeate flux of the fiber sintered at $1400{ }^{\circ} \mathrm{C}$ is twice as high compared to that sintered at $1500{ }^{\circ} \mathrm{C}$, and this result is owing to the higher average pore size and porosity of the former. The salt rejections, which were detected by measuring conductivity, are both greater than $99.9 \%$. In addition, the feeding temperature dependence of the permeate flux is investigated with the as-prepared fiber sintered at $1400^{\circ} \mathrm{C}$. As shown in Figure 6, the permeate flux increases with the temperature of feed solution in the range of $50{ }^{\circ} \mathrm{C}$ to $70{ }^{\circ} \mathrm{C}$, that is expected from the relation between temperature and 
vapor pressure which is the driving force in VMD. The high permeate flux of $60 \mathrm{Lm}^{-2} \mathrm{~h}^{-1}$ is obtained at a feed temperature of $70^{\circ} \mathrm{C}$ and the salt rejections under three of the feed temperatures are all greater than $99.9 \%$ over a period of $4.5 \mathrm{~h}$. These results demonstrate that the as-prepared hydrophobic fiber is eminently suitable for VMD. A list of the permeate flux values for ceramic membranes published recently is summarized in Table 2. The permeate flux depends principally on the feed solution and the configuration. A variety of configurations including direct contact membrane distillation (DCMD), air-gap membrane distillation (AGMD), sweeping-gas membrane distillation (SGMD) and vacuum membrane distillation (VMD) have been used for MD. They can be distinguished by the driving method inclusive of a condensing fluid contacting with the membrane (DCMD), an air gap between the condensing surface and membrane (AGMD), a sweeping gas (SWMD) and a vacuum condition at the permeate side. The choice of configuration used for MD is dependent on the feeding composition, volatility, flux and operation. DCMD is easy to operate and needs the least equipment. VMD generally exhibits a high permeate flux due to the driving from vacuum. SGMD is usually used to remove a volatile organic from an aqueous solution. AGMD is widely used due to its characteristic of collecting separately at permeate side. All of them can be applied to seawater desalination. For the purpose of comparison, the permeate flux is plotted as a function of feed solution temperature in Figure 7. It is seen that the permeate flux value is much greater than those in the published data using a ceramic membrane with various configurations. The greater permeate flux shown in this study is attributed to the appropriate pore size (Figure 3), high porosity and the symmetrical finger-like structure (Figure 4e), which provides macro voids that enhance the mass transfer. On the other hand, it is believed that high contact angle, well permeation and the appropriate $\mathrm{LEP}_{\mathrm{w}}$ value are indispensable to MD. Furthermore, checking the durability of the as-prepared hollow fiber over longer periods will be the subject of future work.

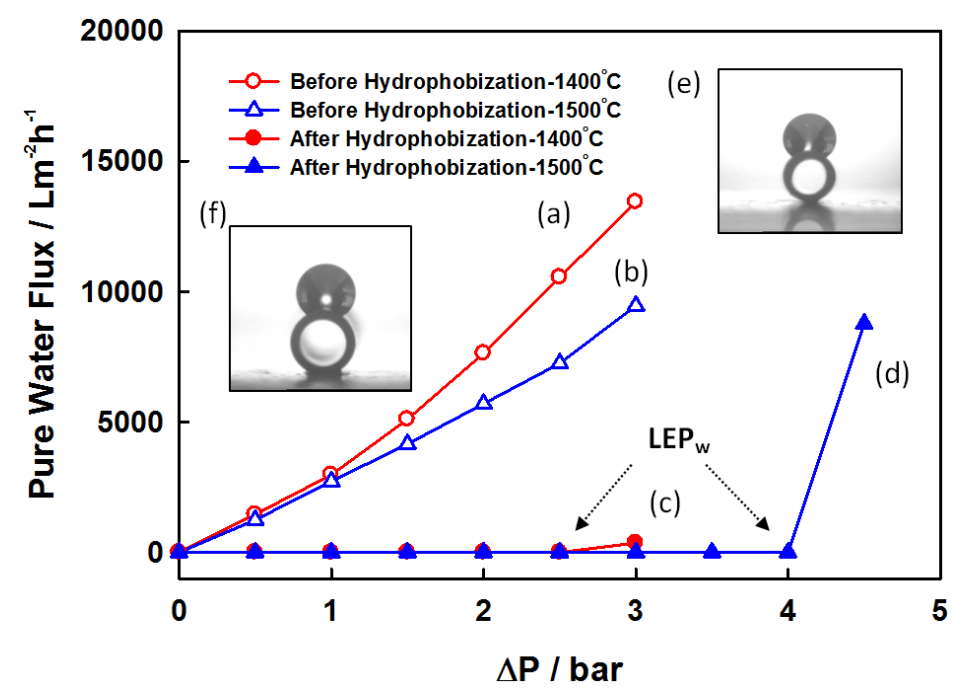

Figure 4. Pure water permeation for as-prepared alumina hollow membrane: before hydrophobization/ sintered at (a) $1400{ }^{\circ} \mathrm{C}$, (b) $1500{ }^{\circ} \mathrm{C}$; after hydrophobization / sintered at (c) $1400{ }^{\circ} \mathrm{C}$, (d) $1500{ }^{\circ} \mathrm{C}$; contact angle after hydrophobization/sintered at (e) $1400{ }^{\circ} \mathrm{C}$, (f) $1500{ }^{\circ} \mathrm{C}$. 


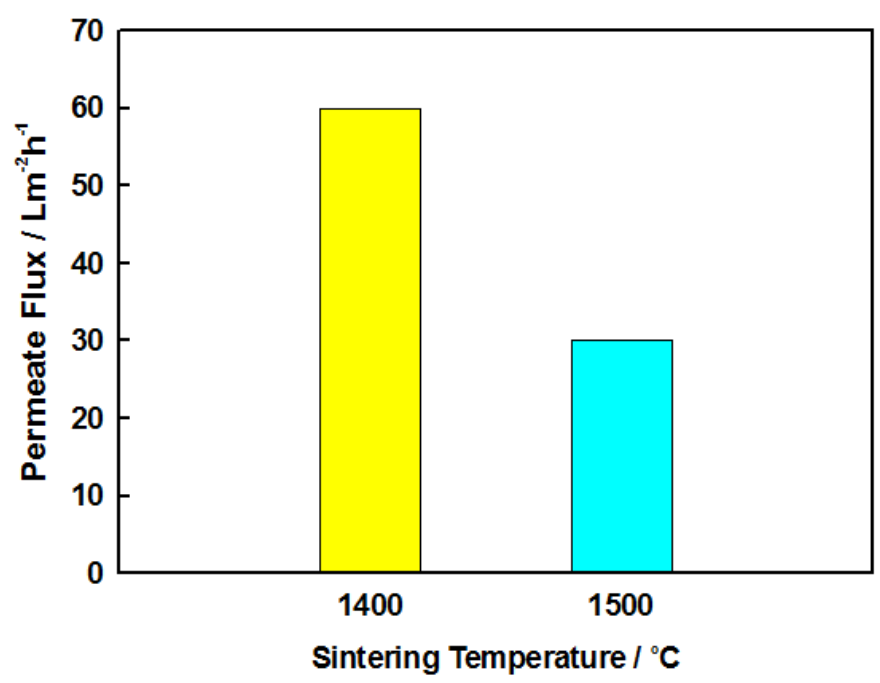

Figure 5. The membrane distillation (MD) permeate flux of as-prepared hydrophobic hollow fiber sintered at different temperatures in vacuum membrane distillation (VMD).

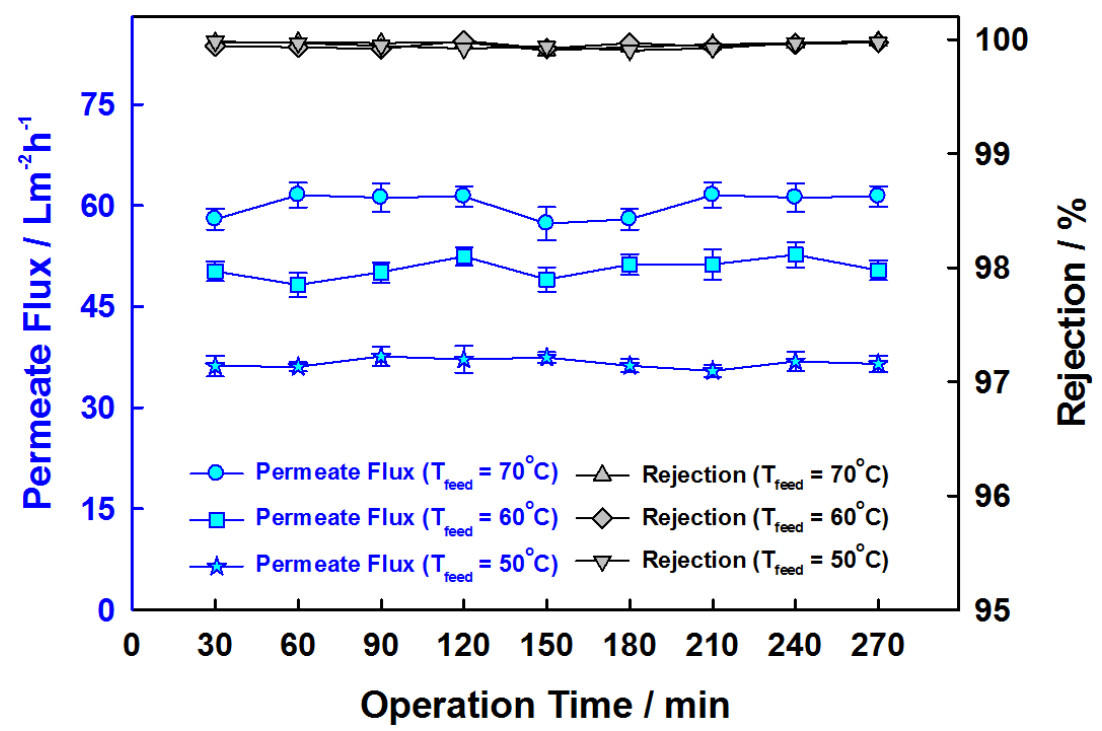

Figure 6. The performance of as-prepared hydrophobic hollow fiber sintered at $1400{ }^{\circ} \mathrm{C}$ with different feeding temperature $\left(70,60\right.$ and $\left.50^{\circ} \mathrm{C}\right)$ in VMD.

Table 2. A list of the MD permeate flux values for ceramic membranes published recently.

\begin{tabular}{|c|c|c|c|c|c|c|}
\hline Configuration & $\begin{array}{c}\text { Membrane } \\
\text { Material }\end{array}$ & $\begin{array}{l}\text { Membrane } \\
\text { Morphology }\end{array}$ & $\begin{array}{l}\mathrm{NaCl} \text { Feed } \\
\text { Solution }\end{array}$ & Hot Side Temp $\left({ }^{\circ} \mathrm{C}\right)$ & $\begin{array}{l}\text { MD Permeate } \\
\text { Flux }\left(\mathrm{Lm}^{-2} \mathrm{~h}^{-1}\right)\end{array}$ & Ref. \\
\hline SGMD & $\mathrm{Al}_{2} \mathrm{O}_{3}$ & Disk & $4.0 \mathrm{wt} \%$ & $70^{\circ} \mathrm{C}\left(80^{\circ} \mathrm{C}\right)\left[90^{\circ} \mathrm{C}\right]$ & 9.9 (13.1) [19.8] & [8] \\
\hline AGMD & $\mathrm{ZrO}_{2} / \mathrm{Al}_{2} \mathrm{O}_{3}$ & Tubular & $1.0[\mathrm{M}]$ & $65^{\circ} \mathrm{C}\left(80^{\circ} \mathrm{C}\right)\left[95^{\circ} \mathrm{C}\right]$ & $1.0(2.9)[6.9]$ & [23] \\
\hline AGMD & $\mathrm{Al}_{2} \mathrm{O}_{3} / \mathrm{ZrO}_{2}$ & Tubular & $1.0[\mathrm{M}]$ & $75^{\circ} \mathrm{C}\left(85^{\circ} \mathrm{C}\right)\left[95^{\circ} \mathrm{C}\right]$ & $1.7(2.9)[5.0]$ & [24] \\
\hline AGMD & $\mathrm{ZrO}_{2}$ & Tubular & $0.9 w t \%$ & $50^{\circ} \mathrm{C}\left(60^{\circ} \mathrm{C}\right)\left[70^{\circ} \mathrm{C}\right]$ & $2.3(3.9)[7.0]$ & [25] \\
\hline AGMD & Titania & Tubular & $0.8[\mathrm{M}]$ & $70{ }^{\circ} \mathrm{C}\left(80^{\circ} \mathrm{C}\right)\left[90^{\circ} \mathrm{C}\right]$ & $0.8(1.5)[2.8]$ & [26] \\
\hline DCMD & Titania & Tubular & $0.8[\mathrm{M}]$ & $70^{\circ} \mathrm{C}\left(80^{\circ} \mathrm{C}\right)\left[90^{\circ} \mathrm{C}\right]$ & $0.6(1.0)[2.5]$ & [26] \\
\hline DCMD & $\mathrm{Al}_{2} \mathrm{O}_{3}$ & Planar & $0.5[\mathrm{M}]$ & $53^{\circ} \mathrm{C}$ & 9.0 & [27] \\
\hline VMD & $\mathrm{ZrO}_{2} / \mathrm{Ti}$ & Tubular & $0.1[\mathrm{M}]$ & $40{ }^{\circ} \mathrm{C}$ & 10.8 & [27] \\
\hline AGMD & $\mathrm{ZrO}_{2} / \mathrm{Ti}$ & Tubular & $0.5[\mathrm{M}]$ & $75^{\circ} \mathrm{C}\left(85^{\circ} \mathrm{C}\right)\left[95^{\circ} \mathrm{C}\right]$ & 2.7 (3.3) [4.7] & [27] \\
\hline DCMD & $\mathrm{Al}_{2} \mathrm{O}_{3}$ & Planar & $4.0 \mathrm{wt} \%$ & $60^{\circ} \mathrm{C}\left(70^{\circ} \mathrm{C}\right)\left[80^{\circ} \mathrm{C}\right]$ & $7.1(11.5)$ [17.0] & [28] \\
\hline DCMD & $\mathrm{Al}_{2} \mathrm{O}_{3} / \mathrm{ZrO}_{2}$ & Tubular & $1.0[\mathrm{M}]$ & $60^{\circ} \mathrm{C}\left(95^{\circ} \mathrm{C}\right)$ & $1.1(6.9)$ & [29] \\
\hline
\end{tabular}


Table 2. Cont.

\begin{tabular}{|c|c|c|c|c|c|c|}
\hline Configuration & $\begin{array}{l}\text { Membrane } \\
\text { Material }\end{array}$ & $\begin{array}{l}\text { Membrane } \\
\text { Morphology }\end{array}$ & $\begin{array}{l}\mathrm{NaCl} \text { Feed } \\
\text { Solution }\end{array}$ & Hot Side Temp $\left({ }^{\circ} \mathrm{C}\right)$ & $\begin{array}{l}\text { MD Permeate } \\
\text { Flux }\left(\mathrm{Lm}^{-2} \mathrm{~h}^{-1}\right)\end{array}$ & Ref. \\
\hline VMD & $\mathrm{Si}_{3} \mathrm{~N}_{4}$ & Hollow fiber & $4.0 \mathrm{wt} \%$ & $60^{\circ} \mathrm{C}\left(70^{\circ} \mathrm{C}\right)\left[80^{\circ} \mathrm{C}\right]$ & $14.6(22.9)[27.5]$ & [30] \\
\hline DCMD & $\mathrm{Si}_{3} \mathrm{~N}_{4}$ & Hollow fiber & $4.0 \mathrm{wt} \%$ & $60^{\circ} \mathrm{C}\left(70^{\circ} \mathrm{C}\right)\left[80^{\circ} \mathrm{C}\right]$ & $5.4(7.5)[10.4]$ & [30] \\
\hline VMD & $\mathrm{Al}_{2} \mathrm{O}_{3}$ & Planar & $4.0 \mathrm{wt} \%$ & $60^{\circ} \mathrm{C}\left(70^{\circ} \mathrm{C}\right)\left[80^{\circ} \mathrm{C}\right]$ & $5.8(7.9)[10.4]$ & [31] \\
\hline DCMD & $\beta$-Sialon & Hollow fiber & $4.0 \mathrm{wt} \%$ & $60^{\circ} \mathrm{C}\left(70^{\circ} \mathrm{C}\right)\left[80^{\circ} \mathrm{C}\right]$ & $3.8(5.4)[6.7]$ & [31] \\
\hline VMD & $\mathrm{Al}_{2} \mathrm{O}_{3}$ & Hollow fiber & $4.0 \mathrm{wt} \%$ & $60^{\circ} \mathrm{C}\left(70^{\circ} \mathrm{C}\right)\left[80^{\circ} \mathrm{C}\right]$ & $19.0(32.0)[42.9]$ & [32] \\
\hline VMD & Zeolite $/ \mathrm{Al}_{2} \mathrm{O}_{3}$ & Tubular & $3.5 \mathrm{wt} \%$ & $60^{\circ} \mathrm{C}$ & 12.0 & [33] \\
\hline DCMD & $\mathrm{ZrO}_{2} / \mathrm{Ti}$ & Tubular & $0.5[\mathrm{M}]$ & $75^{\circ} \mathrm{C}\left(85^{\circ} \mathrm{C}\right)\left[95^{\circ} \mathrm{C}\right]$ & $1.7(2.5)[3.8]$ & [34] \\
\hline VMD & $\mathrm{Si}_{3} \mathrm{~N}_{4}$ & Hollow fiber & $4.0 \mathrm{wt} \%$ & $50^{\circ} \mathrm{C}\left(60^{\circ} \mathrm{C}\right)\left[70^{\circ} \mathrm{C}\right]$ & $9.6(14.6)[22.2]$ & [35] \\
\hline SGMD & $\mathrm{Si}_{3} \mathrm{~N}_{4}$ & Planar & $4.0 \mathrm{wt} \%$ & $75^{\circ} \mathrm{C}$ & 6.7 & [36] \\
\hline VMD & $\mathrm{Al}_{2} \mathrm{O}_{3}$ & Disk & $3.5 \mathrm{wt} \%$ & $70{ }^{\circ} \mathrm{C}$ & 37.1 & [37] \\
\hline DCMD & $\mathrm{TiO}_{2}$ & Nanofiber & $3.5 \mathrm{wt} \%$ & $60^{\circ} \mathrm{C}\left(70^{\circ} \mathrm{C}\right)\left[80^{\circ} \mathrm{C}\right]$ & $7.1(9.2)$ [11.9] & [38] \\
\hline VMD & $\mathrm{Al}_{2} \mathrm{O}_{3}$ & Hollow fiber & $3.5 \mathrm{wt} \%$ & $50^{\circ} \mathrm{C}\left(60^{\circ} \mathrm{C}\right)\left[70^{\circ} \mathrm{C}\right]$ & $35.0(47.0)[60.0]$ & This work \\
\hline
\end{tabular}

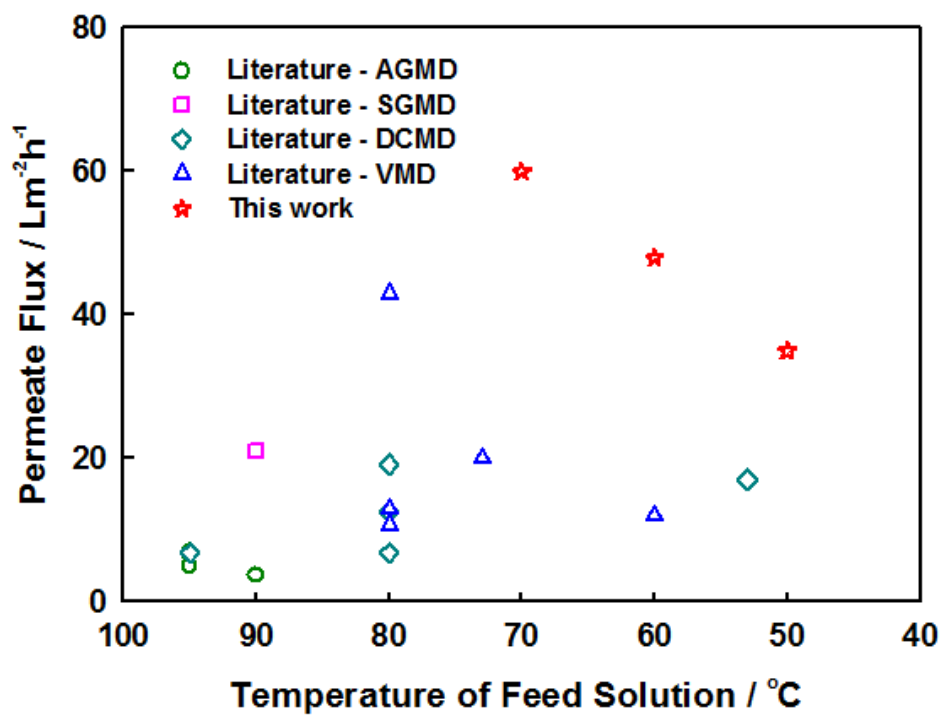

Figure 7. A comparison between the MD permeate flux value obtained from this work and historical data, as a function of feed solution temperature.

\section{Conclusions}

A hydrophobic alumina hollow fiber with high performance in VMD is successfully prepared. The alumina hollow fiber membrane is fabricated using a method that combines phase-inversion and sintering. The as-sintered hollow fiber is hydrophobilized using fluoroalkylsilanes, to obtain a hydrophobic hollow fiber. The hydrophobic hollow fiber prepared at $1400{ }^{\circ} \mathrm{C}$ has a thickness of $230 \mu \mathrm{m}$, an average pore size of $220 \mathrm{~nm}$, porosity of $55 \%$, a contact angle of $137^{\circ}$ and an $\mathrm{LEP}_{\mathrm{w}}$ value of 2.5 bar. It exhibits a high permeate flux value of $60 \mathrm{Lm}^{-2} \mathrm{~h}^{-1}$ which is twice as high compared to that prepared at $1500{ }^{\circ} \mathrm{C}$, and a salt rejection of greater than $99.9 \%$ in $\mathrm{VMD}$ that uses $3.5 \mathrm{wt} \% \mathrm{NaCl}$ aqueous solution at $70{ }^{\circ} \mathrm{C}$ at 0.03 bar. The permeate flux value of $60 \mathrm{Lm}^{-2} \mathrm{~h}^{-1}$ is much greater than previously reported values using ceramic membranes. This hydrophobic alumina hollow fiber is suitable for use in seawater desalination. Checking the durability of the as-prepared hollow fiber over a longer duration will be the subject of future work.

Acknowledgments: The authors would like to thank the Ministry of Science and Technology (MOST), Taiwan, for its financial support (Project numbers 104-2221-E-002-176-MY3, 105-2622-E-002-010-CC1 and 105-2923-E-002 -011-MY2) and acknowledge their gratitude for the collaboration project funding from the Industrial Technology Research Institute, Taiwan.

Author Contributions: C.-C.K., C.-H.C., F.-C.H., C.-L.L. and K.-L.T. conceived and designed the experiments; C.-C.K. performed the experiments; C.-C.K. and Y.-R.C. analyzed the data; Y.-R.C., Y.-H.W. and S.-C.L. contributed reagents/materials/analysis tools; C.-C.K. wrote the paper. 
Conflicts of Interest: The authors declare no conflict of interest.

\section{References}

1. Shirazi, M.M.; Kargari, A.; Shirazi, M.J. Direct contact membrane distillation for seawater desalination. Desalin. Water Treat. 2012, 49, 368-372. [CrossRef]

2. Shiklomanov, I. World fresh water resources. In Water in Crisis: A Guide to the World's Fresh Water Resources; Gleick, P.H., Ed.; Oxford University Press, Inc.: New York, NY, USA, 1993.

3. Drioli, E.; Ali, A.; Macedonio, F. Membrane distillation: Recent developments and perspectives. Desalination 2015, 356, 56-84. [CrossRef]

4. Drioli, E.; Criscuoli, A.; Curcio, E. Membrane Contactors: Fundamentals, Applications and Potentialities; Elsevier Science: Amsterdam, The Netherlands, 2006.

5. Noble, R.D.; Stern, S.A. Membrane Separations Technology: Principle and Applications; Elsevier Science: Amsterdam, The Netherlands, 1995.

6. Alkhudhiri, A.; Darwish, N.; Hilal, N. Membrane distillation: A comprehensive review. Desalination 2012, 287, 2-18. [CrossRef]

7. Ma, Z.; Hong, L.; Su, M. Superhydrophobic membranes with ordered arrays of nanospiked microchannels for water desalination. Langmuir 2009, 25, 5446-5450. [CrossRef] [PubMed]

8. Gu, J.Q.; Ren, C.L.; Zong, X.; Chen, C.S.; Winnubst, L. Preparation of alumina membranes comprising a thin separation layer and a support with straight open pores for water desalination. Ceram. Int. 2016, 42, 12427-12434. [CrossRef]

9. Manawi, Y.M.; Khraisheh, M.A.M.M.; Fard, A.K.; Benyahia, F.; Adham, S. A predictive model for the assessment of the temperature polarization effect in direct contact membrane distillation desalination of high salinity feed. Desalination 2014, 341, 38-49. [CrossRef]

10. Lawson, K.W.; Loyd, D.R. Membrane distillation. J. Membr. Sci. 1997, 124, 1-25. [CrossRef]

11. Khayet, M. Membranes and theoretical modeling of membrane distillation: A review. Adv. Colloid Interface Sci. 2011, 164, 56-88. [CrossRef] [PubMed]

12. Srisurichan, S.; Jiraratananon, R.; Fane, A.G. Humic acid fouling in the membrane distillation process. Desalination 2005, 174, 63-72. [CrossRef]

13. Ding, Z.; Ma, R.; Fane, A.G. A new model for mass transfer in direct contact membrane distillation. Desalination 2003, 155, 205. [CrossRef]

14. Boubakri, A.; Hafiane, A.; Bouguecha, S.A.T. Nitrate removal from aqueous solution by direct contact membrane distillation using two different commercial membranes. Desalin. Water Treat. 2015, 26, 2723-2730. [CrossRef]

15. Sommer, S.; Melin, T. Performance evaluation of microporous inorganic membranes in the dehydration of industrial solvents. Chem. Eng. Process. 2005, 44, 1138-1156. [CrossRef]

16. Lin, Y.F.; Chen, C.H.; Tung, K.L.; Wei, T.Y.; Lu, S.Y.; Chang, K.S. Mesoporous fluorocarbon-modified silica aerogel membranes enabling long-term continuous $\mathrm{CO}_{2}$ capture with large absorption flux enhancements. ChemSusChem 2013, 6, 437-442. [CrossRef] [PubMed]

17. Lin, Y.F.; Wang, C.S.; Ko, C.C.; Chen, C.H.; Chang, K.S.; Tung, K.L.; Lee, K.R. Polyvinylidene fluoride/siloxane nanofibrous membranes for long-term continuous $\mathrm{CO}_{2}$-capture with large absorption-flux enhancement. ChemSusChem 2014, 7, 604-609. [CrossRef] [PubMed]

18. Lin, Y.F.; Ko, C.C.; Chen, C.H.; Tung, K.L.; Chang, K.S. Reusable methyltrimethoxysilane-based mesoporous water-repellent silica aerogel membranes for $\mathrm{CO}_{2}$ capture. RSC Adv. 2014, 4, 1456-1459. [CrossRef]

19. Lin, Y.F.; Ko, C.C.; Chen, C.H.; Tung, K.L.; Chang, K.S.; Chung, T.W. Sol-gel preparation of polymethylsilsesquioxane aerogel membranes for $\mathrm{CO}_{2}$ absorption fluxes in membrane contactors. Appl. Energy 2014, 128, 25-31. [CrossRef]

20. Li, K. Ceramic Membranes for Separation and Reaction; Wiley: Hoboken, NJ, USA, 2007.

21. Lee, M.; Wu, Z.; Wang, R.; Li, K. Micro-structured alumina hollow fiber membranes- Potential applications in wastewater treatment. J. Membr. Sci. 2014, 461, 39-48. [CrossRef]

22. Tan, X.; Liu, N.; Meng, B.; Liu, S. Morphology control of the perovskite hollow fiber membranes for oxygen separation using different bore fluids. J. Membr. Sci. 2011, 378, 308-318. [CrossRef] 
23. Krajewski, S.R.; Kujawski, W.; Bukowska, M.; Picard, C.; Larbot, A. Application of fluoroalkylsilanes (FAS) grafted ceramic membranes in membrane distillation process of $\mathrm{NaCl}$ solutions. J. Membr. Sci. 2006, 281, 253-259. [CrossRef]

24. Gazagnes, L.; Cerneaux, S.; Persin, M.; Prouzet, E.; Larbot, A. Desalination of sodium chloride solutions and seawater with hydrophobic ceramic membranes. Desalination 2007, 217, 260-266. [CrossRef]

25. Khemakhem, M.; Khemakhem, S.; Amar, R.B. Emulsion separation using hydrophobic grafted ceramic membranes by. Colloids Surf. A Physicochem. Eng. Asp. 2013, 436, 402-407. [CrossRef]

26. Kujawa, J.; Cerneaux, S.; Koter, S.; Kujawski, W. Highly efficient hydrophobic titania ceramic membranes for water desalination. Appl. Mater. Interfaces 2014, 6, 14223-14230. [CrossRef] [PubMed]

27. Hendren, Z.D.; Brant, J.; Wiesner, M.R. Surface modification of nanostructured ceramic membranes for direct contact membrane distillation. J. Membr. Sci. 2009, 31, 1-10. [CrossRef]

28. Ren, C.L.; Fang, H.; Gu, J.Q.; Winnubst, L.; Chen, C.S. Preparation and characterization of hydrophobic alumina planar membranes for water desalination. J. Eur. Ceram. Soc. 2015, 35, 723-730. [CrossRef]

29. Larbot, A.; Gazagnes, L.; Krajewski, S.; Bukowska, M.; Kujawski, W. Water desalination using ceramic membrane distillation. Desalination 2004, 168, 367-372. [CrossRef]

30. Zhang, J.W.; Fang, H.; Wang, J.W.; Hao, L.Y.; Xu, X.; Chen, C.S. Preparation and characterization of silicon nitride hollow fiber membranes for seawater desalination. J. Membr. Sci. 2014, 450, 197-206. [CrossRef]

31. Wang, J.W.; Li, L.; Zhang, J.W.; Xu, X.; Chen, C.S. $\beta$-Sialon ceramic hollow fiber membranes with high strength and low thermal conductivity for membrane distillation. J. Eur. Ceram. Soc. 2016, 36, 59-65. [CrossRef]

32. Fang, H.; Gao, J.F.; Wang, H.T.; Chen, C.S. Hydrophobic porous alumina hollow fiber for water desalination via membrane distillation process. J. Membr. Sci. 2012, 403-404, 41-46. [CrossRef]

33. Garofalo, A.; Donato, L.; Drioli, E.; Criscuoli, A.; Carnevale, M.C.; Alharbi, O.; Aljlil, S.A.; Algieri, C. Supported MFI zeolite membranes by cross flow filtration for water treatment. Sep. Purif. Technol. 2014, 137, 28-35. [CrossRef]

34. Cerneaux, S.; Strużyńska, I.; Kujawski, W.M.; Persin, M.; Larbot, A. Comparison of various membrane distillation methods for desalination using hydrophobic ceramic membranes. J. Membr. Sci. 2009, 337, 55-60. [CrossRef]

35. Zhang, J.-W.; Fang, H.; Hao, L.-Y.; Xu, X.; Chen, C.-S. Preparation of silicon nitride hollow fibre membrane for desalination. Mater. Lett. 2012, 68, 457-459. [CrossRef]

36. Wang, J.-W.; Li, L.; Gu, J.-Q.; Yang, M.-Y.; Xu, X.; Chen, C.-S.; Wang, H.-T.; Agathopoulos, S. Highly stable hydrophobic SiNCO nanoparticle-modified silicon nitride membrane for zero-discharge water desalination. AIChE J. 2017, 63, 1272-1277. [CrossRef]

37. Huang, C.-Y.; Ko, C.-C.; Chen, L.-H.; Huang, C.-T.; Tung, K.-L.; Liao, Y.-C. A simple coating method to prepare superhydrophobic layers on ceramic alumina for vacuum membrane distillation. Sep. Purif. Technol. 2016. [CrossRef]

38. Fan, Y.; Chen, S.; Zhao, H.; Liu, Y. Distillation membrane constructed by $\mathrm{TiO}_{2}$ nanofiber followed by fluorination for excellent water desalination performance. Desalination 2017, 405, 51-58. [CrossRef]

(C) 2017 by the authors. Licensee MDPI, Basel, Switzerland. This article is an open access article distributed under the terms and conditions of the Creative Commons Attribution (CC BY) license (http:/ / creativecommons.org/licenses/by/4.0/). 